\title{
Long-Term Activated Sludge Treatment in MBR for Industrial Wastewater Treatment
}

\author{
AL-Saadi Anmar Joudah, Gabriel Racoviteanu
}

\begin{abstract}
Membrane bioreactor (MBR) has been proven as an efficient single step process to treat industrial wastewater and produces a very good effluents quality suitable for reuse. Whereas, it is relatively simple to combine activated sludge with a membrane separation step. MBRs were based on pressurized modules in recirculation loops, but the current state involves submerged membranes functioning by low vacuum. The long-term aeration was adopted in order to obtain the highest efficiency in the biological treatment, wherein the aeration periods were ranged between 07-71 hours. The efficiency of the technology but also of the long-term activated sludge was assessed in combination with sodium hypochlorite addition to remove the adherent bacteria on the surface area of membranes to prevent the clogging. The results showed that there was a significant reduction in both COD and BOD5. As for the total suspended solids, there was fluctuation in concentrations while for nitrate and ammonium concentrations, they were gradual decrease over time, but $\mathrm{NaOCl}$ had a negative effect on these concentrations, where the concentrations of effluents were found to be higher than the influent. For phosphates and orthophosphates, there was a gradual increase over time. However, $\mathrm{NaOCl}$ had a positive effect on the removal efficiency, where removal ratio increased with the increase in $\mathrm{NaOCl}$, and the highest removal efficiency of total phosphate was $\mathbf{5 6 . 4 4 \%}$ while, the highest removal efficiency of orthophosphate was $55.54 \%$.
\end{abstract}

Index Terms - MBR, Industrial Wastewater, $\mathrm{NaOCl}$, Long-Term Aeration, Activated Sludge

\section{INTRODUCTION}

The industrial wastewater varies widely in both flow and pollution strength. So, it is impossible to define fixed values to their components. Generally, industrial wastewaters may contain suspended, colloidal and dissolved (mineral and organic) solids. Also, they may be either excessively acid or alkaline and may contain high or low concentrations of colored matter. These wastes may contain pathogenic bacteria, [1]. Food wastewater contains residues that deplete the oxygen in receiving streams. Chemical oxygen demand $(\mathrm{COD})$ and biochemical oxygen demand $\left(\mathrm{BOD}_{5}\right)$ are important parameters used to determine water quality. $\mathrm{COD}$ and $\mathrm{BOD}_{5}$ are important to the food processing industry because they can be used to indicate lost product and wasteful practices, [2]. For water reuse, contaminants that require

Al-Saadi Anmar Joudah, Dept. of Water Engineering, Technical University of Civil Engineering of Bucharest/ Faculty of Hydrotechnics/ Bucharest/ Sector 2, 124 Lacul Tei Bvd., www.utcb.ro, Romania, Mobile No. +40730484224

Professor Gabriel Racoviteanu, Dept. of Water Engineering, Technical University of Civil Engineering of Bucharest / Faculty of Hydrotechnics / Bucharest, Sector 2, 124 Lacul Tei Bvd., www.utcb.ro, Romania, Mobile No. +40723470737 treatment over and above what is provided by conventional biological treatment include suspended solids and nutrients. Ultrafiltration (UF) hollow fibers membranes are flexible water treatment tools that can be used in a number of process configurations to meet the advanced effluent treatment objectives. Immersed membranes, when used by themselves, are limited to the removal of particulate and colloidal contaminants; however, they can be combined with biological or chemical treatment to remove dissolved contaminants, resulting in the treatment process known as the Membrane Bioreactor (MBR). In this paper, analytical results will be presented for the treatment of industrial wastewater from the waste of the food industry in a meat processing plant in Romania using long terms of activated sludge with MBR system type ZW10 producing from Zenon ${ }^{\circledR}$ (General Electric) Company.

\section{MEMBRANE BIOREACTORS}

ZeeWeed ${ }^{\circledR}$ membrane bioreactor systems combine proven ultrafiltration technology with biological treatment for municipal, commercial and industrial wastewater treatment and water reuse applications. The ZeeWeed ${ }^{\circledR}$ membrane is manufactured by ZENON - General Electric with an OCP chemistry. This chemistry produces a membrane with a pore size of $0.036 \mu \mathrm{m}$. ZeeWeed ${ }^{\circledR}$ is a unique outside-in hollow fiber module that operates under a low vacuum instead of high pressure, [3]. The pilot plant used during the experiments was made available by the company Zenon KFT Hungary, as shown in Figures 1 and 2. The membrane area is $0.93 \mathrm{~m}^{2}$, with dry weight $1.9 \mathrm{~kg}$, and wet weight $2.1 \mathrm{~kg}$. The dimensions of the module are shown in Figure 2.
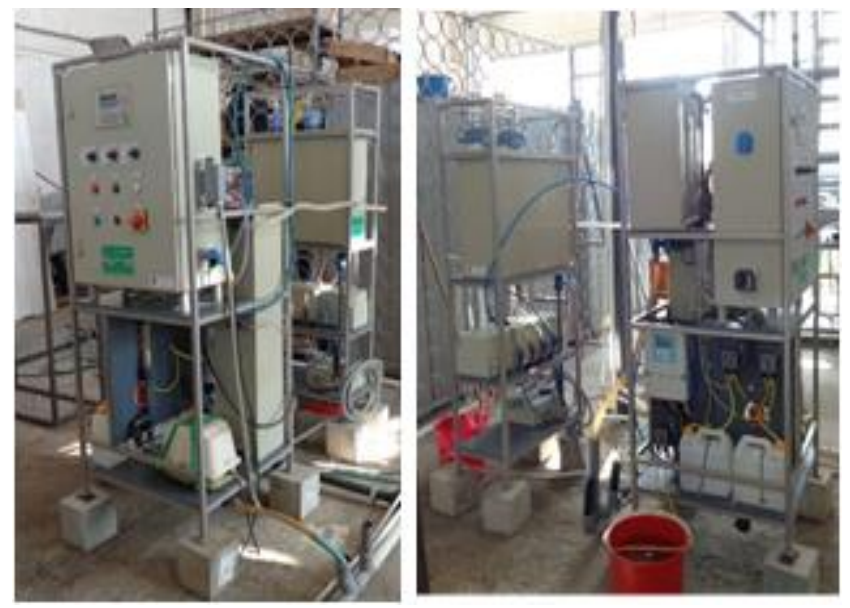

Fig.1. Pilot plant in laboratory water supply "U.T.C.B". 


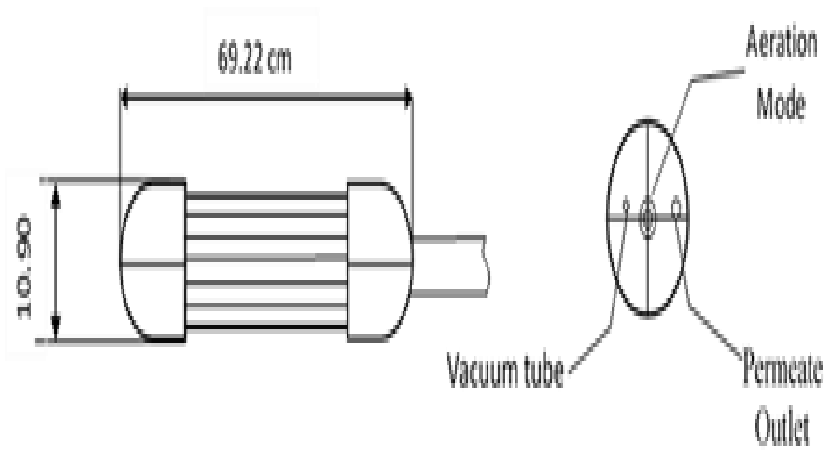

Fig.2. The diagram for membrane module ZW10.

\section{PRACTICAL METHOD}

The long-term aeration was adopted for activating sludge in order to obtain the highest efficiency in the biological treatment, wherein the aeration periods were ranged between 07-71 hours. Activating sludge is the first step that was carried out before the operating in the bioreactor system. Regarding activated sludge process, 1000 liters of industrial wastewater from the food industry was pumped into a plastic container, then 40 liters of activated sludge liquid at a concentration $4396 \mathrm{mg} / \mathrm{l}$ was pumped to the plastic container, after that the air was pumped continuously with the flow rate of $13 \mathrm{l} / \mathrm{min}$ for 71 hours. During the first seven hours of aeration, the liquid mixture was pumped from the plastic tank into the activated sludge tank by using two peristaltic pumps at flow rate 32.31 and $28.31 \mathrm{l} / \mathrm{h}$, then to the bioreactor tank, with air flow rate 10 and $15 \mathrm{l} / \mathrm{min}$ respectively. Six runs were carried out of industrial wastewater treatment for periods of 22, 23, 25, 31, 33 , and 71 hours respectively. The treatment process and backwashing process was programmed at time $600 \mathrm{sec}$, and $30 \mathrm{sec}$ respectively. Sodium hypochlorite $\mathrm{NaOCl}$ was used in bioreactor tank to prevent clogging in the pores of the membranes and control bacteria formation in the bioreactor system. $123 \mathrm{ml}$ of sodium hypochlorite $(\mathrm{NaOCl})$ was added in the Bioreactor tank with wastewater sample at the flow rate of $4.1 \mathrm{ml} / \mathrm{min}$ for the second run R2 (23 hours), and fourth run R4 (31 hours). $340 \mathrm{ml}$ of $\mathrm{NaOCl}$ was pumped to the bioreactor tank at a flow rate $1.02 \mathrm{l} / \mathrm{h}$ for the third run R3 (25 hours).

\section{A. Wastewater Quality Parameters}

The influent and effluents of the bioreactor system were tested for a number of water quality parameters to examine its efficiency in wastewater treatment. These parameters are: $\mathrm{pH}$, Temperature, Total Suspended Solids, TSS, Mixed liquor suspended solids, MLSS, Biochemical Oxygen Demand, $\mathrm{BOD}_{5}$, Chemical Oxygen Demand, COD, Nitrate $\mathrm{NO}_{3}-\mathrm{N}$, Ammonium, $\mathrm{NH}_{4}-\mathrm{N}$, Total Phosphate, $\mathrm{TP}$, and Ortho Phosphate, OP.

\section{B. Water Sampling and Testing}

Fourteen samples were taken from plastic tank, activated sludge tank, and effluents tank, as shown in Table 1. A sample of raw wastewater was taken as soon as it reached to the laboratory. After 7 hours of aeration for the mixed liquor, a sample of the plastic tank was taken from the mixed liquor for analysis. The treatment process was run for a period of time ranging from 22 hours to 71 hours to determine the BOD removal efficiency, COD removal efficiency, and suspended solids removal efficiency, as well as determine the effect of the chemical compound represented by $\mathrm{NaOCl}$ on the treatment efficiency. The $\mathrm{pH}$ and temperature were measured on-site before sampling.

\section{RESULTS AND DISCUSSIONS UNITS}

The samples were tested for fifteen physical and biochemical tests.

Table 1. Description of samples has been taken from the first experimented test.

\begin{tabular}{|c|c|}
\hline No. & Description \\
\hline 1 & $\begin{array}{l}\text { The } 1000 \mathrm{ml} \text { of influent were taken from plastic tank at 11:00 am } \\
\text { on } 22 / 09 / 2017 \text {. }\end{array}$ \\
\hline 2 & $\begin{array}{l}\text { The } 1000 \mathrm{ml} \text { of influent were taken from activated sludge tank at } \\
06: 00 \mathrm{pm} \text { on 22/09/2017. }\end{array}$ \\
\hline 3 & $\begin{array}{l}\text { The } 1000 \mathrm{ml} \text { of influent were taken from activated sludge tank at } \\
\text { 09:00 am on 23/09/2017. }\end{array}$ \\
\hline 4 & $\begin{array}{l}\text { The } 1000 \mathrm{ml} \text { of effluents were taken at 09:00 am on 23/09/2017 } \\
\text { without additives. }\end{array}$ \\
\hline 5 & $\begin{array}{l}\text { The } 1000 \mathrm{ml} \text { of influent were taken from activated sludge tank at } \\
10: 00 \text { am on } 23 / 09 / 2017 \text {. }\end{array}$ \\
\hline 6 & $\begin{array}{l}\text { The } 1000 \mathrm{ml} \text { of effluents were taken at } 10: 00 \text { am on } 23 / 09 / 2017 \text {, } \\
\text { where } 123 \mathrm{ml} \text { of sodium hypochlorite was pumped into the } \\
\text { bioreactor tank at a flow rate } 4.1 \mathrm{ml} / \mathrm{min} \text { for } 30 \mathrm{~min} \text {. }\end{array}$ \\
\hline 7 & $\begin{array}{l}\text { The } 1000 \mathrm{ml} \text { of influent were taken from activated sludge tank at } \\
12: 00 \mathrm{pm} \text { on } 23 / 09 / 2017 \text {. }\end{array}$ \\
\hline 8 & $\begin{array}{l}\text { The } 1000 \mathrm{ml} \text { of effluents were taken at } 12: 00 \mathrm{pm} \text { on } 23 / 09 / 2017 \text {, } \\
\text { where } 340 \mathrm{ml} \text { from sodium hypochlorite was pumped to the } \\
\text { bioreactor tank at a flow rate } 1.02 \mathrm{l} / \mathrm{h} \text { for } 20 \mathrm{~min} \text {. }\end{array}$ \\
\hline 9 & $\begin{array}{l}\text { The } 1000 \mathrm{ml} \text { of influent were taken from activated sludge tank at } \\
06: 00 \mathrm{pm} \text { on 23/09/2017. }\end{array}$ \\
\hline 10 & $\begin{array}{l}\text { The } 1000 \mathrm{ml} \text { of effluent were taken at } 06: 00 \mathrm{pm} \text { on } 23 / 09 / 2017 \text {, } \\
\text { where } 123 \mathrm{ml} \text { of sodium hypochlorite was pumped into the } \\
\text { bioreactor tank at a flow rate } 4.1 \mathrm{ml} / \mathrm{min} \text { for } 30 \mathrm{~min} \text {. }\end{array}$ \\
\hline 11 & $\begin{array}{l}\text { The } 1000 \mathrm{ml} \text { of influent were taken from activated sludge tank at } \\
\text { 08:00 pm on 23/09/2017. }\end{array}$ \\
\hline 12 & $\begin{array}{l}\text { The } 1000 \mathrm{ml} \text { of effluents were taken at 09:00 am on 23/09/2017 } \\
\text { without additives. }\end{array}$ \\
\hline 13 & $\begin{array}{l}\text { The } 1000 \mathrm{ml} \text { of influent were taken from activated sludge tank at } \\
10: 00 \text { am on } 25 / 09 / 2017 \text {. }\end{array}$ \\
\hline 14 & $\begin{array}{l}\text { The } 1000 \mathrm{ml} \text { of effluents were taken at 10:00 am on 25/09/2017 } \\
\text { without additives. }\end{array}$ \\
\hline
\end{tabular}

The biochemical tests consist of mixed liquor suspended solids, total suspended solids, biochemical oxygen demand, chemical oxygen demand, nitrate, ammonium, total phosphate, and orthophosphate, whereas the physical tests were carried out on the site which consists of $\mathrm{pH}$ and temperature. The data of these tests results are presented in Table 2. Analysis of these results is presented in the following subsections:

\section{A. Temperature}

The temperature of influent and effluent varied between 23.3 and $21{ }^{\circ} \mathrm{C}$ as shown in Figure 3. The maximum and 
minimum temperature of influent were found, $22.7^{\circ} \mathrm{C}$ and $21^{\circ} \mathrm{C}$, respectively, whereas, the maximum and the minimum of effluents were found $23.3^{\circ} \mathrm{C}$ and $21^{\circ} \mathrm{C}$ respectively. The average temperature of the influent and effluents were 22.41 and $22.6^{\circ} \mathrm{C}$, respectively. There is no significant difference in temperature, but the effluents temperatures were in general higher than the influent.

\section{B. $p H$ value}

The variations of $\mathrm{pH}$ value are shown in Figure 4 . The maximum, minimum, and average measurements for influent were $8.75,7.88$, and 8.42 respectively, whereas, the maximum, minimum, and average measurements for-

\begin{tabular}{|c|c|c|c|c|c|c|c|c|c|c|c|c|c|c|c|}
\hline & & & & & & & & & & & & & & & \\
\hline & & S1 & S2 & S3 & S4 & S5 & S6 & S7 & S8 & S9 & S10 & S11 & S12 & S13 & S14 \\
\hline No. & Parameters & $\begin{array}{l}\text { Waste } \\
\text { water }\end{array}$ & $\begin{array}{l}\text { I1, } \\
7 \text { h }\end{array}$ & $\begin{array}{r}12, \\
22 \text { h }\end{array}$ & $\begin{array}{l}\text { E2, } \\
22 \text { h }\end{array}$ & $\begin{array}{r}13, \\
23 \mathrm{~h}\end{array}$ & $\begin{array}{r}\text { E3, } \\
23 \text { h }\end{array}$ & $\begin{array}{l}\text { I4, } \\
25 \mathrm{~h}\end{array}$ & $\begin{array}{r}\text { E4, } \\
25 \text { h }\end{array}$ & $\begin{array}{l}\text { I5, } \\
31 \text { h }\end{array}$ & $\begin{array}{r}\text { E5, } \\
31 \text { h }\end{array}$ & $\begin{array}{l}\text { I6, } \\
33 \mathrm{~h}\end{array}$ & $\begin{array}{l}\text { E6, } \\
33 \text { h }\end{array}$ & $\begin{array}{r}\text { I7, } \\
71 \mathrm{~h}\end{array}$ & $\begin{array}{l}\text { E7, } \\
71 \text { h }\end{array}$ \\
\hline 1 & $\mathrm{COD} \mathrm{mgo}_{2} / \mathrm{l}$ & 2120.5 & 1017.6 & 864 & 384 & 832 & 158.4 & 775 & 268.8 & 710.4 & 115.2 & 770 & 259.2 & 960 & 297.6 \\
\hline 2 & $\mathrm{BOD}_{5} \mathrm{mgo}_{2} / \mathrm{l}$ & 1150 & 625 & 643 & 217 & 640 & 3 & 620 & 4.2 & 551 & 2.8 & 620 & 179 & 632 & 150 \\
\hline 3 & TSS mg/l & 530 & - & - & 288 & - & 300 & - & 484 & - & 280 & - & 186 & - & 28 \\
\hline & MLSS mg/l & - & 638 & 720 & - & 680 & - & 640 & - & 434 & - & 430 & - & 420 & - \\
\hline 4 & $\begin{array}{l}\text { Total Phosphate } \\
\mathrm{mg} / \mathrm{l}\end{array}$ & 15.2 & 15.4 & 15.45 & 11 & 15.5 & 12.3 & 15.54 & 6.77 & 15.6 & 10.7 & 15.8 & 13.1 & 16 & 15.3 \\
\hline 5 & $\begin{array}{l}\text { Orthophosphate } \\
\mathrm{mg} / \mathrm{l}\end{array}$ & 14.19 & 14.35 & 14.5 & 9.84 & 14.56 & 11.7 & 14.62 & 6.5 & 14.82 & 8.54 & 15.3 & 12.5 & 15.5 & 13.5 \\
\hline 10 & $\mathrm{~N}-\mathrm{NO}_{3} \mathrm{mg} / \mathrm{l}$ & 0.955 & 0.974 & 0.948 & 0.461 & 0.947 & 0.789 & 0.945 & 17.7 & 0.94 & 1.99 & 0.938 & 0.424 & 0.873 & 0.695 \\
\hline 11 & $\mathrm{~N}-\mathrm{NH}_{4} \mathrm{mg} / \mathrm{l}$ & 20.25 & 19.9 & 7.68 & 6.17 & 7.42 & 6.96 & 6.21 & 86.8 & 5.35 & 47.7 & 5.34 & 4.93 & 4.31 & 2.73 \\
\hline 14 & PH & 6.97 & 7.88 & 8.21 & 9.03 & 8.23 & 9.33 & 8.56 & 10.72 & 8.73 & 10.35 & 8.75 & 9.16 & 8.56 & 9 \\
\hline 15 & Temperature ${ }^{\circ} \mathrm{C}$ & 22 & 22.5 & 22.7 & 22.9 & 22.6 & 22.7 & 22.7 & 23.3 & 22.7 & 23 & 22.68 & 22.7 & 21 & 21 \\
\hline
\end{tabular}

Table 2. Data results of the samples collected from the first biochemical tests.

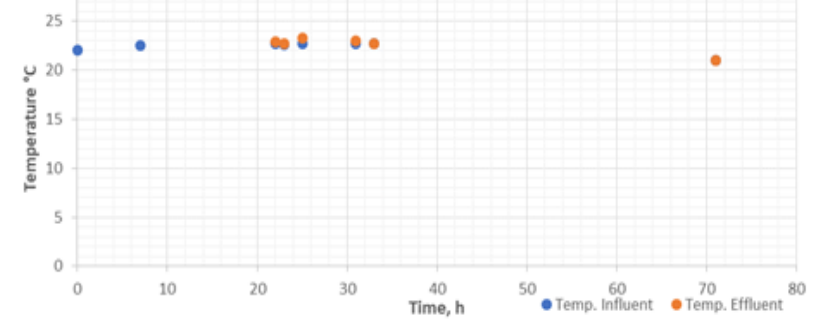

Fig.3. Variation of the temperature.

-effluents were 10.72, 9.00, and 9.60 respectively. All the effluents values of $\mathrm{pH}$ were higher than in the influent. Also, from the results it was observed the excessive increase of $\mathrm{pH}$ due to the effect of the $\mathrm{NaOCl}$, wherein the $\mathrm{pH}$ value increased when the $\mathrm{NaOCl}$ amount increased.

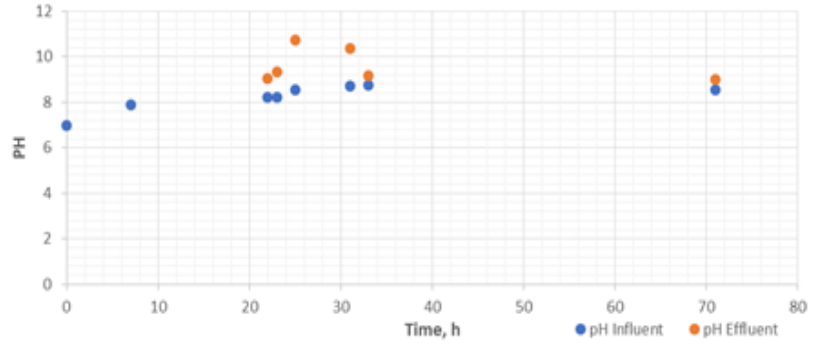

Fig. 4. Variation of the pH value.

\section{A. Total Suspended Solids TSS}

The results of tested values for total suspended solids during the runs are shown in Figure 5, these results were obtained for effluents of runs. The maximum, minimum and average value of these runs were 484, 28, and $261 \mathrm{mg} / \mathrm{l}$ respectively. The results obtained are shown that increased of

TSS concentrations with the increased of the $\mathrm{NaOCl}$ amount and decreased with the time. That means the addition of sodium hypochlorite leads to reduced removal efficiency as shown in Figure 5.

\section{B. Mixed Liquor Suspended Solids MLSS}

The results of tested values for mixed liquor suspended solids are shown in Figure 5, these results were obtained for influent of runs. The maximum, minimum and average value of these runs were 720,420 , and $566 \mathrm{mg} / \mathrm{l}$ respectively. The results obtained are shown that decreased of MLSS concentrations with the time during long-term aeration that means the decline of the number of microorganisms represented by sludge due to the consumption of organic matter in the wastewater. 


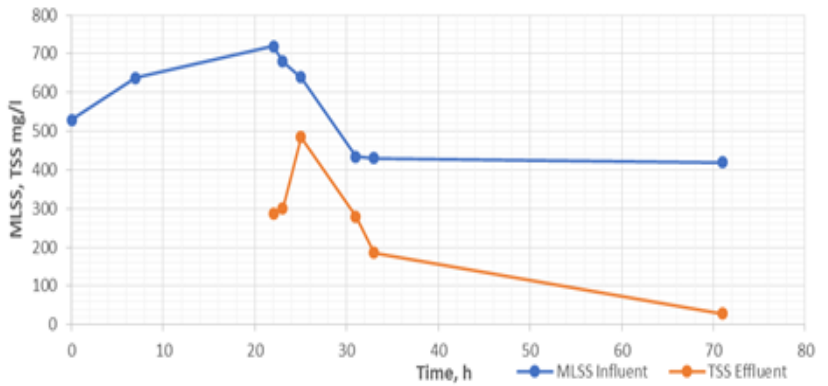

Fig. 5. Variations of TSS and MLSS concentrations.

\section{Biochemical Oxygen Demand $\mathrm{BOD}_{5}$}

The tested of the $\mathrm{BOD}_{5}$ values are shown in Figure 6. The maximum, minimum, and average value of influent were 643, 551 , and 618 respectively, where the value of $\mathrm{BOD}_{5}$ for raw wastewater was $1150 \mathrm{mg} / \mathrm{l}$. While the maximum, minimum and average values of effluents were $217,2.80$, and 92.67 $\mathrm{mg} / \mathrm{l}$ respectively. The results show a significant reduction in $\mathrm{BOD}_{5}$ values when $123 \mathrm{ml}$ of $\mathrm{NaOCl}$ was added, thus achieving the highest removal efficiency.

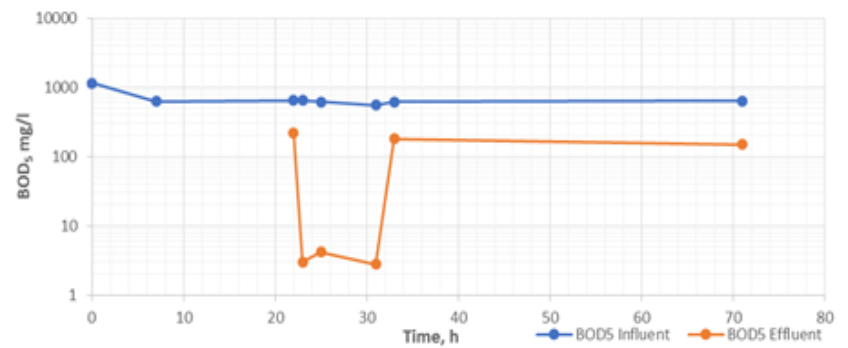

Fig. 6. Variations of the concentration of $\mathrm{BOD}_{5} \mathrm{mg} / 1$.

\section{Chemical Oxygen Demand COD}

The tested of the COD values are shown in Figure 7. The maximum, minimum, and average value of influent were 1017.6, 710.4, and $847 \mathrm{mg} / \mathrm{l}$ respectively, where the value of COD for raw wastewater was $2120.5 \mathrm{mg} / \mathrm{l}$, whereas, the maximum, minimum and average values of effluents were $384,115.2$, and $247.2 \mathrm{mg} / \mathrm{l}$ respectively. The results show a reduction in $\mathrm{COD}$ values when $123 \mathrm{ml}$ of $\mathrm{NaClO}$ was added, thus achieving the highest removal efficiency.

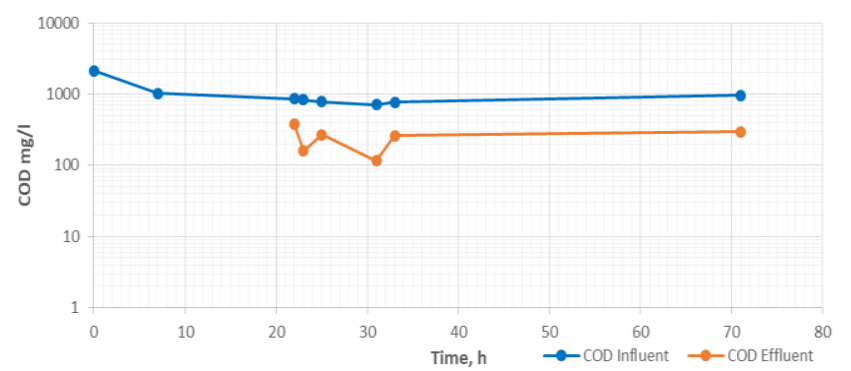

Fig. 7. Variations of the concentration of COD $\mathrm{mg} / \mathrm{l}$.

\section{E. Nitrate nitrogen $\mathrm{NO}_{3}-\mathrm{N}$}

The tested of $\mathrm{NO}_{3}-\mathrm{N}$ values are shown in Figure 8. In this test, there was a negative effect of sodium hypochlorite $\mathrm{NaOCl}$ on the effluents in terms of removal, where the values of the nitrate concentrations in effluents were higher than in the influent. The maximum, minimum, and average value of influent were $0.97,0.87$, and 0.94 respectively. Whereas, the maximum, minimum and average value of effluent were 17.7, 0.42 , and $3.68 \mathrm{mg} / \mathrm{l}$, respectively.

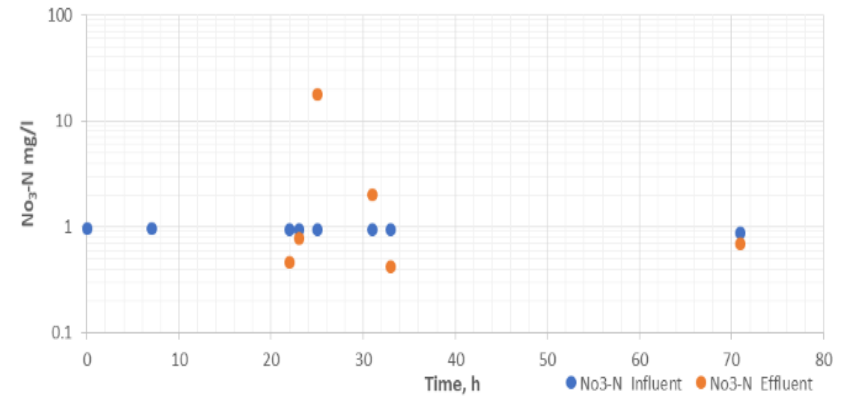

Fig. 8. Variations of the concentration of $\mathrm{NO}_{3}-\mathrm{N}$ $\mathrm{mg} / 1$.

\section{F. Ammonium nitrogen $\mathrm{NH}_{4}-\mathrm{N}$}

The tested of $\mathrm{NH}_{4}-\mathrm{N}$ values are shown in Figure 9. In this test, there was a negative effect of sodium hypochlorite $\mathrm{NaOCl}$ on the effluents in terms of removal, where the values of the ammonium concentrations in effluents were higher than in the influent. The maximum, minimum, and average value of influent were $19.90,4.31$, and $8.03 \mathrm{mg} / \mathrm{l}$ respectively. Whereas, the maximum, minimum and average value of effluent were $87,2.73$, and $25.88 \mathrm{mg} / \mathrm{l}$, respectively.

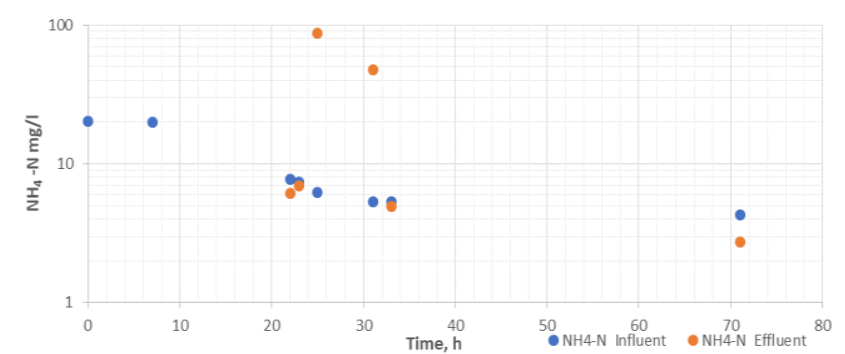

Fig. 9. Variations of the concentration of $\mathrm{NH}_{4}-\mathrm{N}$ $\mathrm{mg} / 1$.

\section{G. Total Phosphate $\mathrm{PO}_{4}-\mathrm{P}$}

Total phosphate represents the three forms of phosphate, orthophosphate, and polyphosphate and organically bound phosphate. The tested of total phosphate concentrations are shown in Figure 10. The maximum, minimum, and average values of influent were $16.00,15.40$, and $15.61 \mathrm{mg} / \mathrm{l}$ respectively. While, the maximum, minimum, and average values of effluents were $15.30,6.77$, and $11.53 \mathrm{mg} / \mathrm{l}$ respectively. Where the sodium hypochlorite compound has effect on the decreasing of total phosphate concentrations and obtain the highest efficiency of removal.

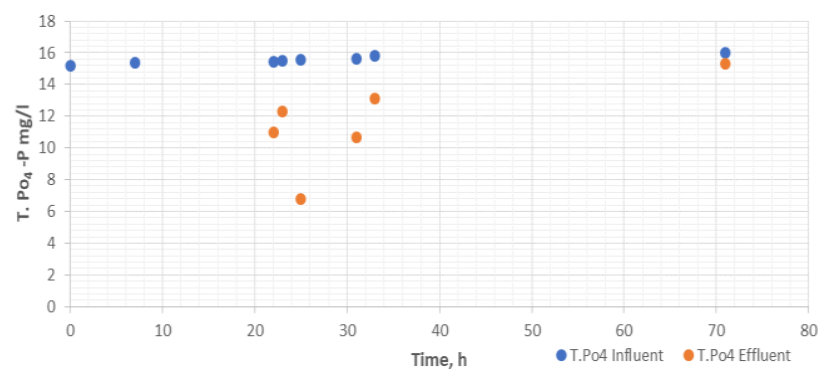

Fig. 10. Variations of the concentration of $\mathrm{TP} \mathrm{mg} / \mathrm{l}$.

\section{H. Orthophosphate $\mathrm{PO}_{4}-\mathrm{P}$}

Orthophosphate is the simplest series of the phosphates, and is usually called only phosphate. The tested of orthophosphate concentrations are shown in Figure 11. The 
maximum, minimum, and average values of influent were $15.50,14.35$, and $14.81 \mathrm{mg} / \mathrm{l}$ respectively, whereas, the maximum, minimum, and average values of effluents were $14.00,6.50$, and $10.43 \mathrm{mg} / \mathrm{l}$ respectively. Where the sodium hypochlorite compound has effect on the decreasing of orthophosphate concentrations and obtain the highest efficiency of removal.

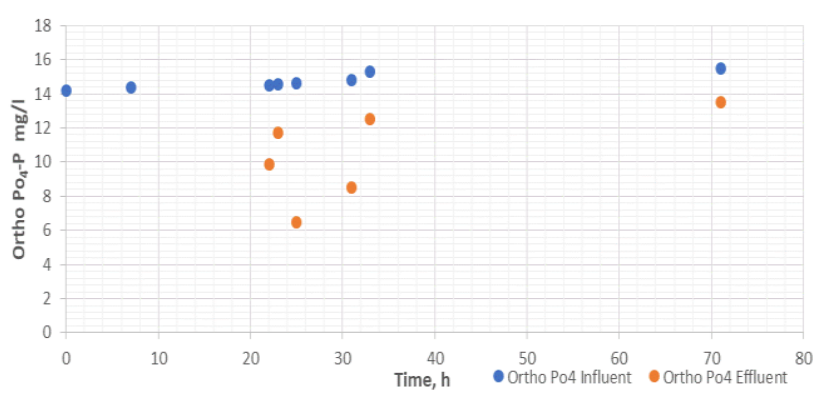

Fig. 11. Variations of the concentration of Ortho-P $\mathrm{mg} / \mathrm{l}$.

\section{CONCLUSIONS}

The experimental trials aimed assessment of the long-term treatment method was used to activate the sludge for 22-71 hours. The wastewater was treated by using ZW10 hollow fiber membranes.

Sodium hypochlorite has been added to the bioreactor tank with mixed liquor to study its effect on the treatment process. Sodium hypochlorite is used as a disinfectant in water as well as to prevent clogging in the pores of the membranes. The results obtained can be summarized as follows:

1. Regarding of activated sludge process, a significant reduction was observed in both concentrations of COD and $\mathrm{BOD}_{5}$. Where the COD was decreased from 2120.5 to $1017.6 \mathrm{mg} / \mathrm{l}$, while the $\mathrm{BOD}_{5}$ concentration decreased from 1150 to $625 \mathrm{mg} / \mathrm{l}$. The $\mathrm{pH}$ value was also increased during the aeration process, where the $\mathrm{pH}$ value increased from 6.97 to 7.88 . While there was no clear effect on the other parameters.

2. For the treatment process, the effect of sodium hypochlorite on effluents was observed. The best results were generally obtained after 23 hours of aeration when $123 \mathrm{ml}$ was added to the bioreactor tank. The parameters that had a positive effect are $\mathrm{BOD}_{5}, \mathrm{COD}$, nitrate, and ammonium, where they were within acceptable limits, [4]. Whereas the other parameters had a negative effect. These parameters are the total suspended solids, total phosphate, orthophosphate, and $\mathrm{pH}$, with concentrations, $300 \mathrm{mg} / \mathrm{l}, 12.3 \mathrm{mg} / \mathrm{l}, 11.7 \mathrm{mg} / \mathrm{l}$, and 9.33 , respectively.

3. The increase in the $\mathrm{NaOCl}$ compound has a negative effect on all parameters except total phosphate and orthophosphate, this increase led to decrease of the phosphate concentrations.

4. For removal efficiency, the best COD removal efficiency was $80.96 \%-83.78 \%$. As for the $\mathrm{BOD}_{5}$ was 99.53-99.49\%, while the highest removal efficiency of suspended solids is $93.33 \%$ after 71 hours of aeration.

\section{REFERENCES}

[1] Mohamed Nazih Abdallh, Walid Sayed Abdelhalim, Hisham Sayed Abdelhalim, "Industrial Wastewater Treatment of Food Industry Using Best Techniques," International Journal of Engineering Science Invention, www.ijesi.org, vol. 5, no. 8, pp. 15-28, August 2016.

[2] R. MCILVAINE, "WATER \& WASTEWATER TREATMENT IN THE FOOD INDUSTRY,".

https://www.wwdmag.com/sites/wwdmag.com/files/22_Mcllvane_C olumn_IWWD0715.pdf, 2015.

[3] G. W. \&. P. T. -. Z. M. Solutions, "Process Overview: ZeeWeed ${ }^{\circledR}$ MBR,"

www.wateronline.com/doc/process-overview-zeeweed-mbr-0001, 2005.

[4] ZDHC, "Wastewater Guidelines - ZDHC," 2016. [Online]. Available: http://www.roadmaptozero.com/fileadmin/pdf/Files_2016/ZDHC_W astewater_Guidelines_Print.pdf.

Al-Saadi Anmar Joudah, I am a doctoral student at the Technical University of Civil Engineering Bucharest, Faculty of Hydrotechnics, specialization, Water Treatment Engineering, My Research Project on Industrial Wastewater Treatment in Romania, this article is one of the results obtained during the study. achievements, with photo that will be maximum 200-400 words.
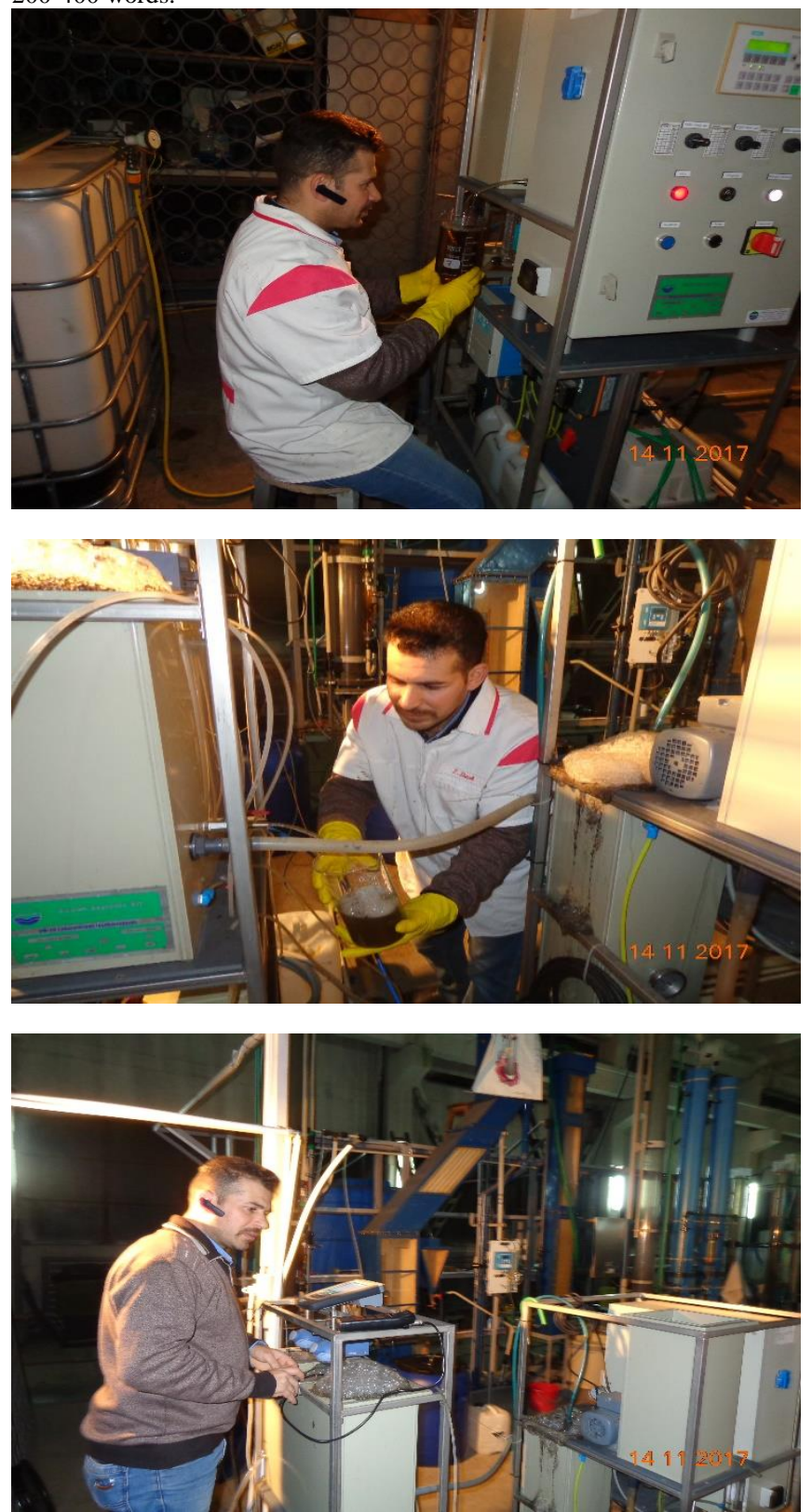